\title{
ASO Author Reflections: Emerging Risk Factors in Colon Cancer-End of the Line for Clinomics?
}

\author{
Erik Osterman, $\mathrm{MD}^{1,2}$ (1) , and Bengt Glimelius, $\mathrm{MD}, \mathrm{PhD}^{1,3}$ \\ ${ }^{1}$ Department of Immunology, Genetics and Pathology, Uppsala University, Uppsala, Sweden; ${ }^{2}$ Department of Surgery, \\ Gävle Hospital, Gävle, Sweden; ${ }^{3}$ Department of Oncology, Uppsala University Hospital, Uppsala, Sweden
}

\section{PAST}

The risk of recurrence after colon cancer surgery today is less than seen in the past, likely ascribed to higher quality in staging, surgery, and pathology. ${ }^{1}$ Further stratification of patients is needed to guide treatment decisions, especially in the light of the IDEA collaboration findings. ${ }^{2}$ Many clinicopathological risk factors of recurrence have been suggested over the years but not always tested with the routinely used risk factors suggested in guidelines. ${ }^{3} \mathrm{We}$ sought to test routinely collected, emerging, risk factors not incorporated in guidelines in a well-characterized cohort against the baseline of clinicopathological data and risk factors suggested in NCCN guidelines.

\section{PRESENT}

We found that all emerging risk factors correlated with worse clinical features and with recurrences. However, after adjusting for $\mathrm{T}$ - and $\mathrm{N}$-stage, and $\mathrm{NCCN}$ risk factors it appears obvious that several risk factors are symptoms of advanced disease and not independent risk factors. In unadjusted analyses pT4a was worse than pT4b, replicating the results from our national Swedish registry study. Carcinoembryonic antigen (CEA) was previously

\footnotetext{
ASO Author Reflections is a brief invited commentary on the article, "Beyond the NCCN risk factors in colon cancer: an evaluation in a Swedish population-based cohort," Ann Surg Oncol. (2020) https://d oi.org/10.1245/s10434-019-08148-3.
}

(C) The Author(s) 2019

First Received: 15 October 2019; Published Online: 28 December 2019

E. Osterman, MD

e-mail: erik.osterman@igp.uu.se recommended as a risk factor before surgery. We found that if CEA was elevated after surgery, but before initiation of adjuvant chemotherapy, as many as $48 \%$ recurred compared with $16 \%$ if not. ${ }^{4}$

\section{FUTURE}

Testing CEA after surgery, but before chemotherapy, should be investigated further, because it could help to better stratify patients. The finding of worse outcomes for pT4a than pT4b patients suggests that the terminology for pT4 subclassification may need to be reversed, again, to preserve the logic of the system, if the finding holds.

Future attempts to improve risk stratification of patients with colon cancer should consider clinomics, potentially with additional evaluation of the histopathological pattern, and adjust for them, but look further into molecular and genomic factors. Predicting treatment response and evaluating residual disease is currently a hot topic, with ctDNA taking a strong position. ${ }^{5}$ Risk stratification with clinomics and biomarkers for treatment decisions, determination of residual disease for treatment length and intensity of follow-up could be the future.

ACKNOWLEDGEMENTS Open access funding provided by Uppsala University.

\section{DISCLOSURES The authors report no conflicts of interest.}

OPEN ACCESS This article is licensed under a Creative Commons Attribution 4.0 International License, which permits use, sharing, adaptation, distribution and reproduction in any medium or format, as long as you give appropriate credit to the original author(s) and the source, provide a link to the Creative Commons licence, and indicate if changes were made. The images or other third party material in this article are included in the article's Creative Commons licence, unless indicated otherwise in a credit line to the material. If material is not included in the article's Creative Commons licence and your intended 
use is not permitted by statutory regulation or exceeds the permitted use, you will need to obtain permission directly from the copyright holder. To view a copy of this licence, visit http://creativecommons. org/licenses/by/4.0/.

\section{REFERENCES}

1. Osterman E, Glimelius B. Recurrence risk after up-to-date colon cancer staging, surgery, and pathology: analysis of the entire Swedish population. Dis Colon Rectum. 2018;61(9):1016-25. h ttps://doi.org/10.1097/dcr.0000000000001158

2. Grothey A, Sobrero AF, Shields AF, et al. Duration of adjuvant chemotherapy for stage III colon cancer. $N$ Engl $J$ Med. 2018;378(13):1177-88. https://doi.org/10.1056/nejmoa1713709

3. Benson AB, Venook AP, Al-Hawary MM, et al. National comprehensive cancer network. Colon Cancer (Version 2.2019).
May 2019. https://www.nccn.org/professionals/physician_gls/pdf/ colon.pdf. Accessed 10 June 2019.

4. Osterman E, Mezheyeuski A, Sjöblom T, Glimelius B. Beyond the NCCN risk factors in Colon cancer: an evaluation in a Swedish population-based cohort. Ann Surg Oncol. 2020. https://doi.org/10. 1245/s10434-019-08148-3.

5. Wang Y, Li L, Cohen JD, et al. Prognostic potential of circulating tumor DNA measurement in postoperative surveillance of nonmetastatic colorectal cancer. JAMA Oncol. 2019. https://doi.org/ 10.1001/jamaoncol.2019.0512.

Publisher's Note Springer Nature remains neutral with regard to jurisdictional claims in published maps and institutional affiliations. 